\title{
複断面蛇行河川における洪水時の低水路 内岸側河床の最大洗掘深調查

\author{
INVESTIGATION OF THE MAXIMUM SCOUR DEPTH ON THE INNER \\ BED OF MAIN CHANNEL IN A COMPOUND MEANDERING CHANNEL
}

\author{
福岡捷二 1 - 道中 貢 $^{2}$. 平生昭二 ${ }^{3}$ \\ Shoji FUKUOKA, Mitsugu MICHINAKA and Shoji HIRAO \\ 1 正会員 工博, Ph.D. 広島大学教授 工学部第四類建設系 (干739 東広島市鏡山1-4-1) \\ 2 正会員 建設省中国地方建設局浜田工事事務所工務第一課 \\ 3 学生会貝 広島大学大学院 工学研究科博士前期 環境工学専攻
}

\begin{abstract}
From the result of laboratory experiment, in a compound meandering channel, we suggested the possibility of inner bank erosion due to channel plan shape and flood scale (relative depth ratio, duration). Actually, we received report of inner bank erosion in natural river flood.

In this reseach, bed topography of inner bank of main channel in meandering compound river was studied. For the investigation, at first we bored some circular holes on inner bed, and then filled by painted soil of different color in six layers. We measured maximum depth of erosion at inner bed by the indication of colored sediment after the flood. It was observed from the investigation that the erosion occured at inner bed for long period and large scale flood.
\end{abstract}

Key Word : compound meandering channel, inner bed topography of main channel, maximum scour depth at inner bed, sinuosity, flood scale

\section{1. 序論}

複断面蛇行河道の低水路内岸側は外岸側に比べ 河床変動や河岸侵食の面から安定していると考えら れ, 河床洗掘については主に外岸側に着目した検討 が行われてきた. そのため, 河道の内岸側が多自然 型川づくりのポイントとして, また橋脚の設置位置 等に選ばれてきた. しかし, 河道の平面形特に低水 路の蛇行度や洪水の水位, 継続時間によっては低水 路内岸側河岸が洗掘被災したケースが報告がされて (るる?.

近年, 低水路亡堤防の間に位相差がある複断面 蛇行流れに関する研究は, 固定床実験を中心に精力 的に行われ, その流況や流れの構造が明らかにされ ている(2)3,4,5,5,9.9. その結果, 複断面蛇行流れを規定す る要因は, 河道線形を表す蛇行度・位相差, 水理条 件を示す相対水深( $\mathrm{Dr}=$ 高水敷水深/低水路水深), 高 水敷流れを支配する高水敷幅と粗度等であることが 明らかになった゚。

複断面蛇行河道の河床変動については, 福岡ら が行った移動床実験により次のような知見が得られ ている ${ }^{7,8), 9}$. それは, 高水敷が広い複断面蛇行流路
では，河床変動は主に内岸から内岸に向かった最大 流速線上で起こり, 外岸側河床の変動は小さいこと である. また相対水深の変化によって, 洗掘(最大 流速)位置が蛇行部外岸側に現れる単断面的蛇行流 れ之, 蛇行部内岸側に現れる複断面的蛇行流れが存 在することである. この2つの洪水流れが存在する ことは, 実河川の洪水実測デー夕を分析し, 蛇行部 頂点におりる最大流速位置, 蛇行度, 相対水深から 複断面蛇行河道における洪水流の分類を行った結果 からも裏付けされている10).このため実河川では, 継続時間の長い大規模な洪水が発生すると, 内岸側 の河床之河岸が洗掘される河岸災害が起こる可能性 がある ${ }^{111}$. 従って, 洪水中の内岸側の河床変動機構 と深さを明らかにすることは, 内岸砂州の利用, 河 川構造物の設置, 河道の維持管理を適正に行う上で 重要である.

実河川では洪水時の河床高を多点で同時に測定 することは, 技術的に困難であり, 洪水の前後に測 定された河床高から洗掘量, 堆積量を判断してき た. しかし, この方法では洪水中の河床変動や最大 洗掘深等を知ることができない. 本研究では, 洪水 中の内岸側の河床変動の理解を得るために, 平常時 
には露出している蛇行部の内岸砂州上にボーリング 孔を多数掘削し，掘削した土層ごとに着色して埋め 戻した. そして, 洪水後に掘り返してその深さを調 查することによって, 洪水時の内岸側河床の最大洗 掘深とその後の洪水減水時の土砂の堆積量の調查を 行った. 現在, この調查を全国の河川で行っている が本論文では江の川の調査結果について速報する.

\section{2. 低水路内岸側河床における最大洗掘深の調} 查方法

\section{(1) 調査地点の選定}

洪水時の内岸側河床の最大洗掘深の調查を行う地 点は，以下の点に留意して選定した.

(1) 図-1のa点やb点(低水路最大曲率断面の位置より やや下流)のように低水路と堤防の間に位相差が ある河道弯曲部の高水敷幅が広い区間で, 河道 の蛇行度( $\mathrm{S}=$ 低水路中心距離 / 堤防中心距離)が 1.02よりも大きく, 平常時には内岸砂州が露出し ている河床を選ぶ.

(2) 洪水流量(水位)ハイドログラフが求まる区間流量 観測, 水位観測が行われている地点の近く.

(3) 調查区間の上下流 $200 \mathrm{~m} に は$ 樹木が存在せず, 洪 水時に河床が移動していると想定される内岸砂 州区間.

ここで蛇行度を1.02以上の区間を選ぶのは，著者 らが行った複断面蛇行流水の洪水流特性分類図 ${ }^{10)}$ で 内岸側の流速が外岸よりも速くなる蛇行度を基準に している.

\section{(2) 調查方法}

調查方法は, 以下に示す方法で行った。

(1) 図-2に示すように直径 $0.5 \mathrm{~m}$, 深さ $1.5 \mathrm{~m}$ 程度の円 形ボーリング孔を内岸砂州上に掘削する．各深

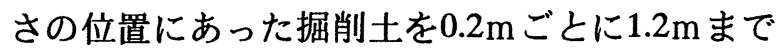
6 段階に着色した後, 元の位置に埋め戻す.（こ の際, 初期河床高と各層の高さがわかるように しておく．また，掘削した土層の粒度試験も同 時に行う. )

(2) 各観測位置でのボーリング孔の数は内岸側断面 での洗掘深の平面分布が分かる程度掘る. (図-3)

(3) 観測区間を含む区間の水面勾配を測定する.

(4) 洪水後, 調查箇所の地盤高を測定する. そし て, 着色して埋め戻した層の内, どの層まで移 動したかをボーリング孔ごとに調べる.これに より, 洪水時の最大洗掘深と堆積量を知ること ができる.

(5) 調查は, 相対水深 0.30 以上の中・大洪水を対象に 少なくとも 2 洪水について行う.

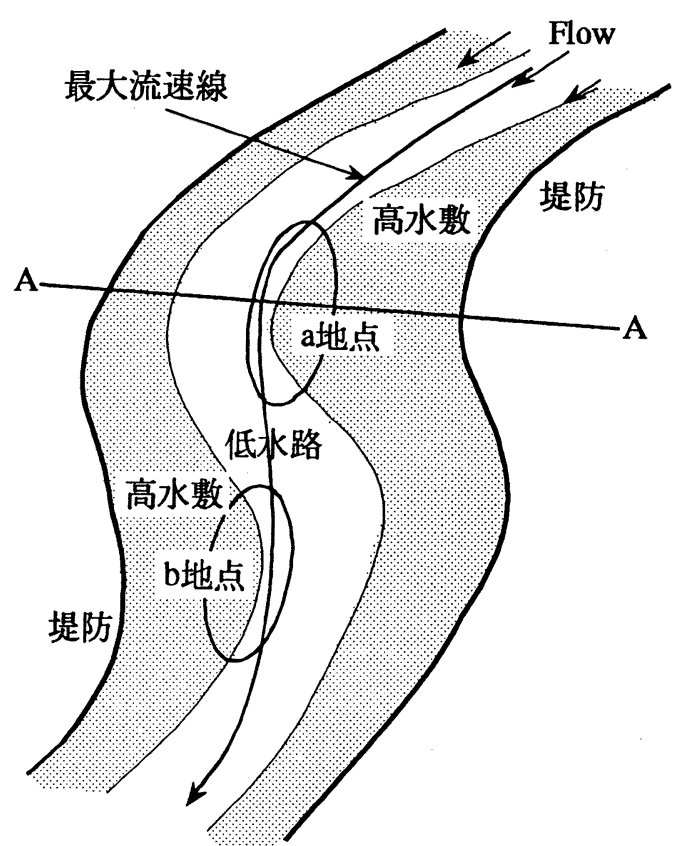

図-1 堤防と低水路に位相差が存在する河道線形と 最大流速発生位置

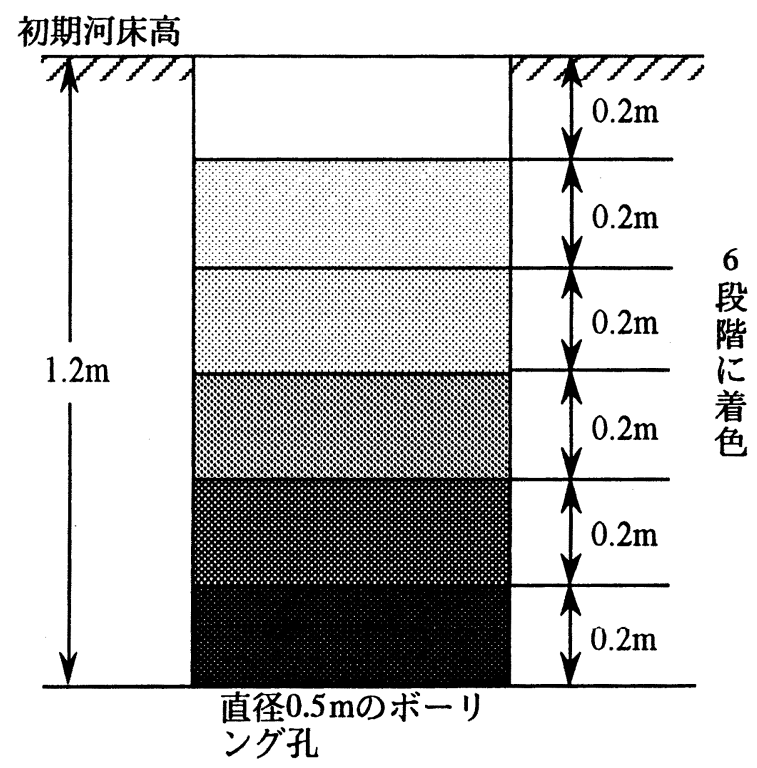

図-2 ボーリング孔と着色した廉

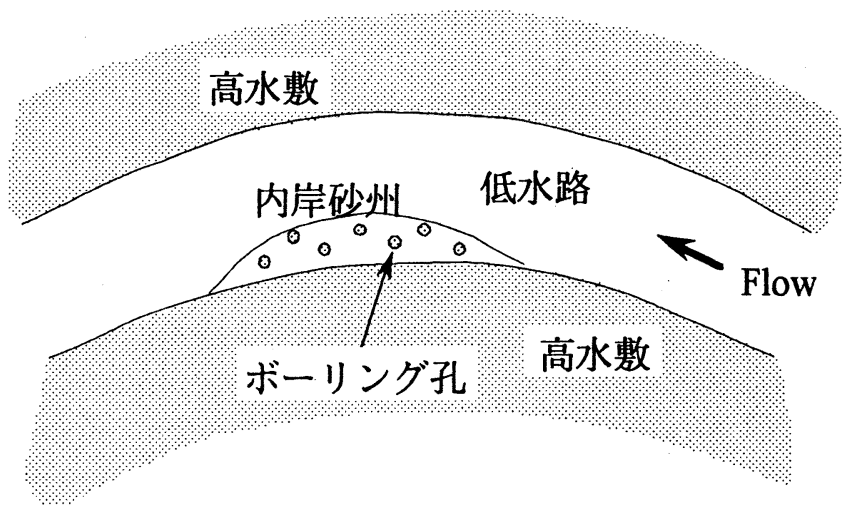

図-3 調查地点(a,b地点)の拡大図 


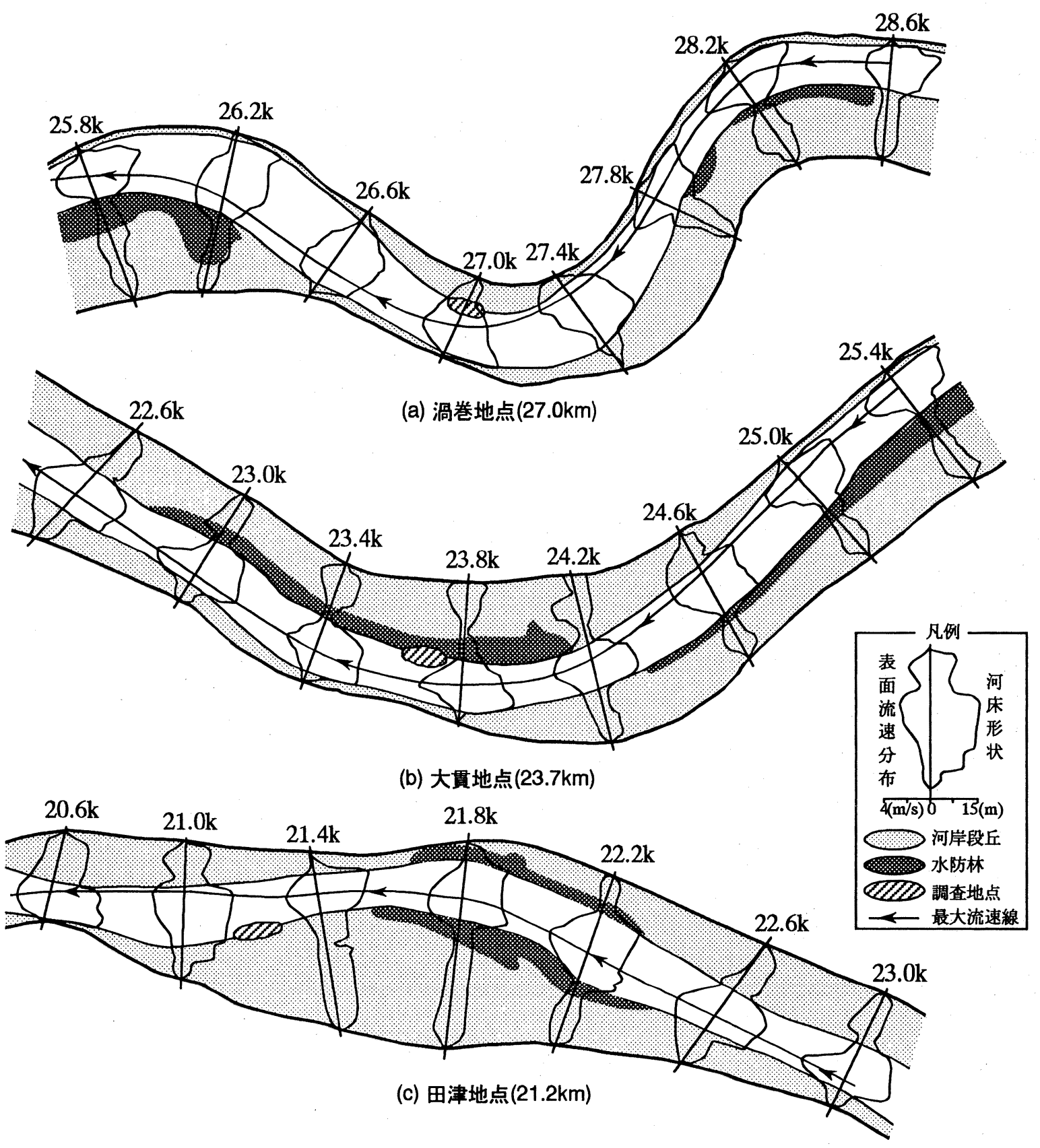

図-4 江の川の平面形と昭和58年7月洪水時の表面流速分布，河床形状と今回の調査地点

\section{3. 江の川及び対象洪水}

\section{(1) 江の川の地形的特徵}

江の川は，峡谷を貫入する典型的な穿入蛇行河川 である. 中国山地の隆起によって下刻作用が進み, 蛇行帯に沿い細長い河岸段丘が発達している.この 河岸段丘は, 江の川の侵食と堆積に支配される平坦 地で，砂，れき，粘土からなる沖積層である.

調查対象区間の河岸段丘の土地は, 主として桑園 として利用され，その他に茶畑，畑地がある．後背 湿地は水田である．河岸段丘には水防林の役割を持 つマダケの竹林が繁茂している。この水防林は, 洪 水時には河岸や高水敷を守る反面，流れには大きな
抵抗となり河道の踈通能力を小さくしている.

低水路の内岸付近河床の洗掘深調查を行った区間 (30km〜20km付近)は, 両側に河岸段丘が発達して いる河道である. 調查地点は渦巻( $27.0 \mathrm{~km}$ 付近), 大 貫(23.7km付近), 田津(21.2km付近)の3地点であり, それぞれの調查地点を含む河道平面形を図-4に示 す. 各調查地点がある蛇行部の蛇行度は 1.093 , $1.030,1.029$ である.

図-5に各調查地点におけるボーリング孔No.1の粒 径加積曲線を示す. 渦巻地点では9割弱が砂分であ るのに対し，大貫, 田津地点は6〜8割が礫分で，こ の2地点は同様な粒度分布をとる. 


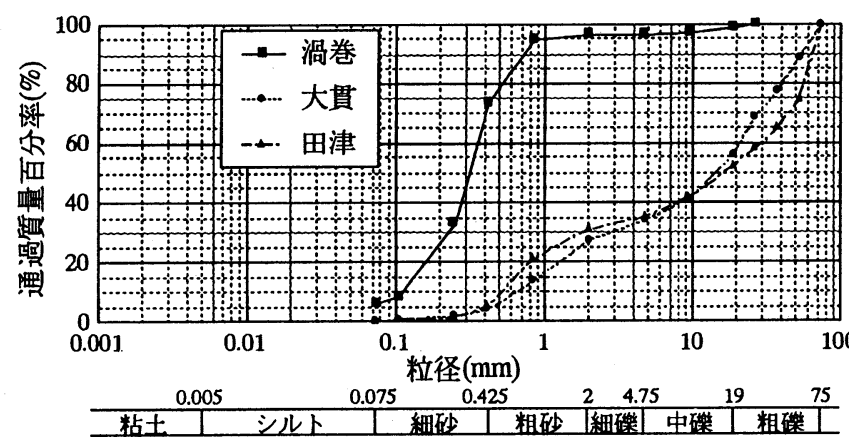

図-5 各調查地点の粒径加積曲線

(ボーリング孔No.1)

\section{(2) 過去の出水状況}

過去の水害を調べると江の川の出水は，5月，6月 に多い.これは, 梅雨前線の南下と山陰の地形によ りもたらされる集中豪雨によるものである.この梅 雨豪雨の一つである昭和58年7月洪水時の表面流速 分布と洪水後の河床横断形状を示したものが図-4で ある.この時, 桜江町 $(16.0 \mathrm{~km}) て ゙$ 総雨量が $441 \mathrm{~mm}$ 記録し，山崩れや河川の氾濫が相次いだ．洪水規模 について見ると, 水位観測所である川本地点 $(36.3 \mathrm{~km})$ において，ピーク水位から算出した相対水 深は0.60で, 冠水時間は100時間以上であった.

この洪水は, 図-4に示す様に複断面的蛇行流れの 典型的な洪水で, 矢印で示す様に蛇行部の内岸から 内岸の経路上に最大流速が現れている. 洪水後の河 床から屯蛇行部頂点の $27.2 \mathrm{~km}$ 断面で洗掘位置が, 外 岸から低水路中央付近に移動していた ${ }^{10}$. 江の川で は昭和58年7月規模の洪水が発生すると蛇行部内岸 側が洗掘される可能性が高い.

\section{(3) 対象洪水}

本調查は，平成9年7月 8 月〜 13日の梅雨前線によ る洪水を対象とした.

図-6は水位観測所のある川本地点 $(36.3 \mathrm{~km})$ におけ る河床横断面形状と水位-時間曲線, そして大津地 点 $(86.5 \mathrm{~km})$ での降雨量である. この時の総雨量は大 津地点で $301 \mathrm{~mm}$, ピーク流量は川本地点で $3500 \mathrm{~m}^{3} /$ $\sec$ (速報値)であった．水位変化は，二山型で河岸段 丘上に乗っている時間が5日間以上と長くなってい る. ピーク水位時の相対水深は0.40で, 昭和58年7 月洪水と比較すると相対水深はやや小さいが, 洪水 継続時間は長くなっている.

\section{4. 調查結果}

調査は, ボーリング孔設置直後, 出水直後の地盤 高及び洪水中の最低地盤高(ボーリング孔の掘削に よる調査)を測定した. 設置後と出水後の地盤高よ り1洪水を通しての河床変動高を, 設置後と掘削後

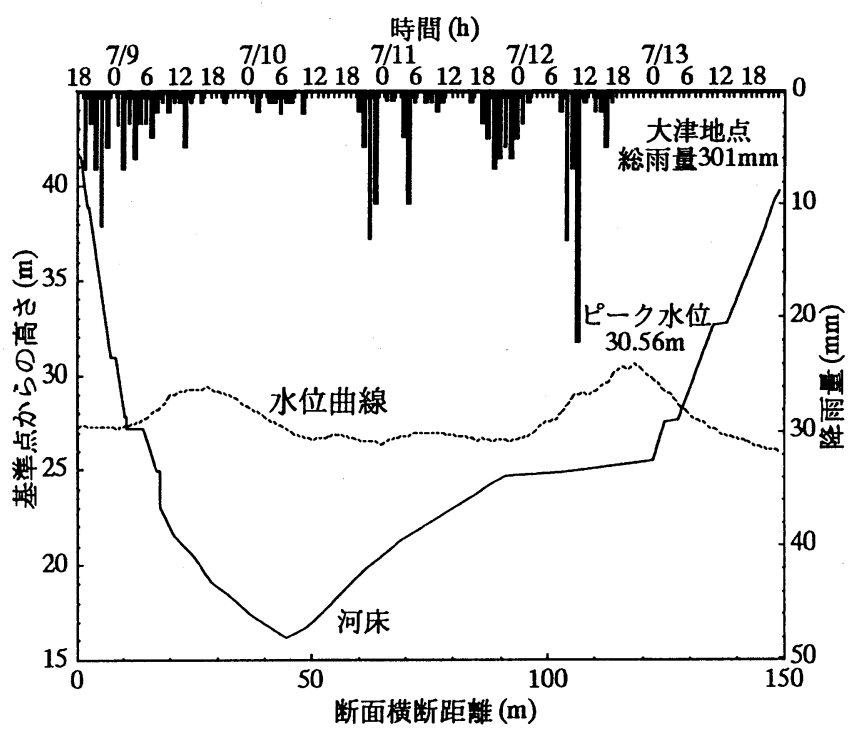

図-6川本地点の河床横断面形状と水位曲線 及び大津地点における降雨量

の差より洪水中の最大洗掘深を, 出水後と掘削後か ら主に洪水の減水期に生じる土砂の堆積量を推定す ることができる. 図-7は, 渦巻, 大貫, 田津の各調 查地点のボーリング孔の平面的な位置関係と調查結 果を示したものである.

\section{(1) 渦巻地点 $(27.0 \mathrm{~km}$ 付近)}

渦巻地点は調查を行った地点の内, 蛇行度が最も 大きい区間( $\mathrm{S}=1.093)$ にある. 調查位置も最大曲率断 面付近の下流の内岸に位置している(図-4). また, この直上流の $27.2 \mathrm{~km}$ 断面では, 昭和58年7月洪水で 内岸側の河床が洗掘されたことを示す測量結果が得 られている゚。.

調查結果より洪水時の最大洗掘深は，No.4を除く 全てのボーリング孔において約 $0.2 \mathrm{~m}$ 程度を記録して いる．この事は，少なくとあ洪水ピーク時には蛇行 部内岸側に最大流速が発生する複断面的蛇行流れが 現れていたことを示す. また，洪水の減水期におこ る内岸での堆積量は少なく，内岸河床は全般的に 0.1 0.2m程度洗掘されている.ここで, No.4の ボーリング孔のみ傾向が異なるのは, 他のボーリン グ孔と比べ磷分を多く含んでいた(約2割)ためである 亡考えられる.

\section{(2) 大貫地点 $(23.7 \mathrm{~km}$ 付近)}

大貫地点は，最大曲率断面付近の下流に位置する が(図-4), 低水路河岸沿いにはマダケの竹林が繁茂 している.

洪水を通して内岸側河床は, 結果的にはほとんど 変動しなかったと判断できる. しかし, 洪水中の最 大洗掘深は, 前面に当たるNo.1〜 4のボーリング孔 で0.4m以上となっている．この事は，洪水の減水期 に現れるBankfull流れの時間帯で外岸洗掘, 内岸堆 


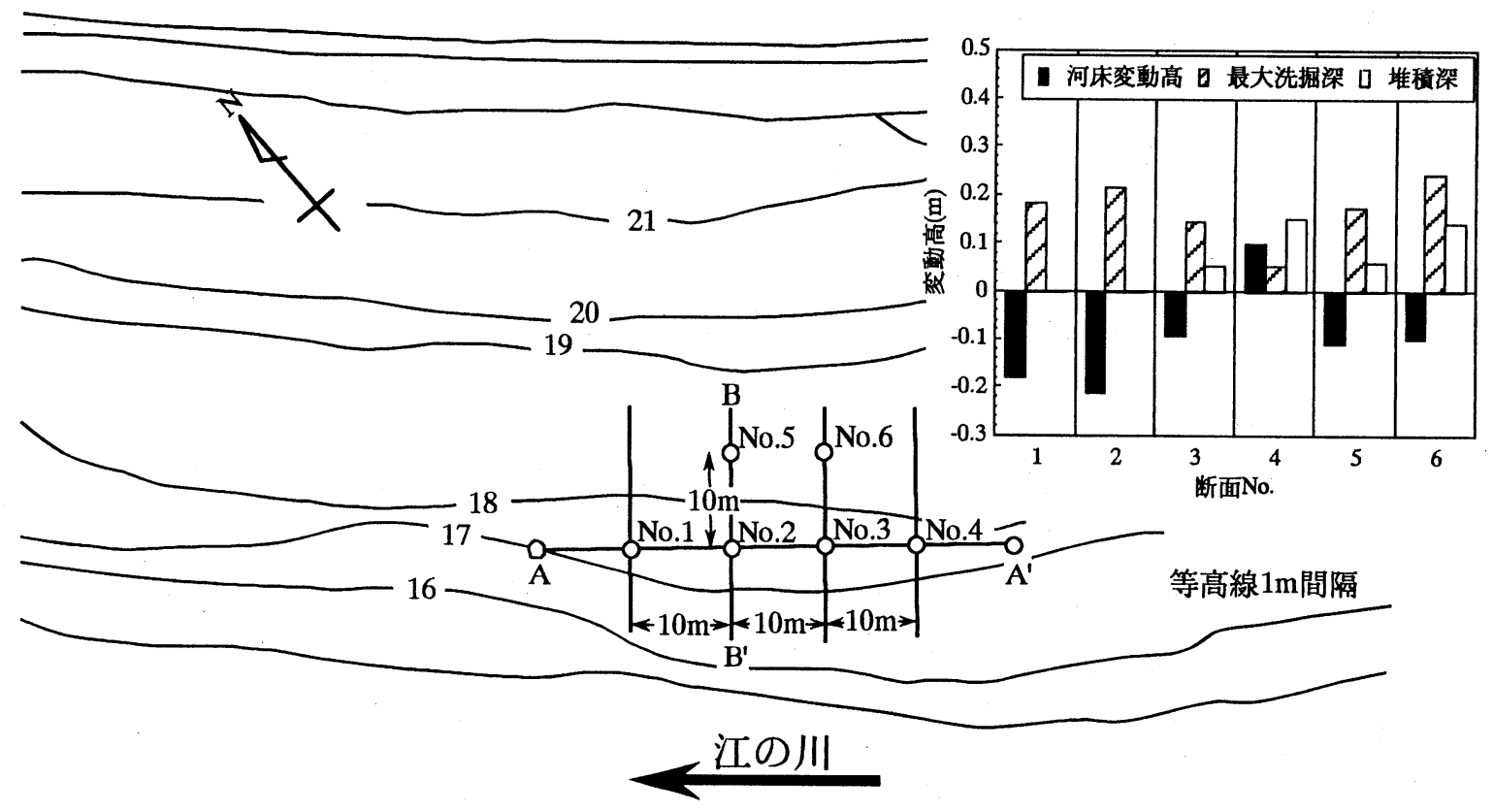

(a) 渦巻地点 $(27.0 \mathrm{~km}$ 付近)

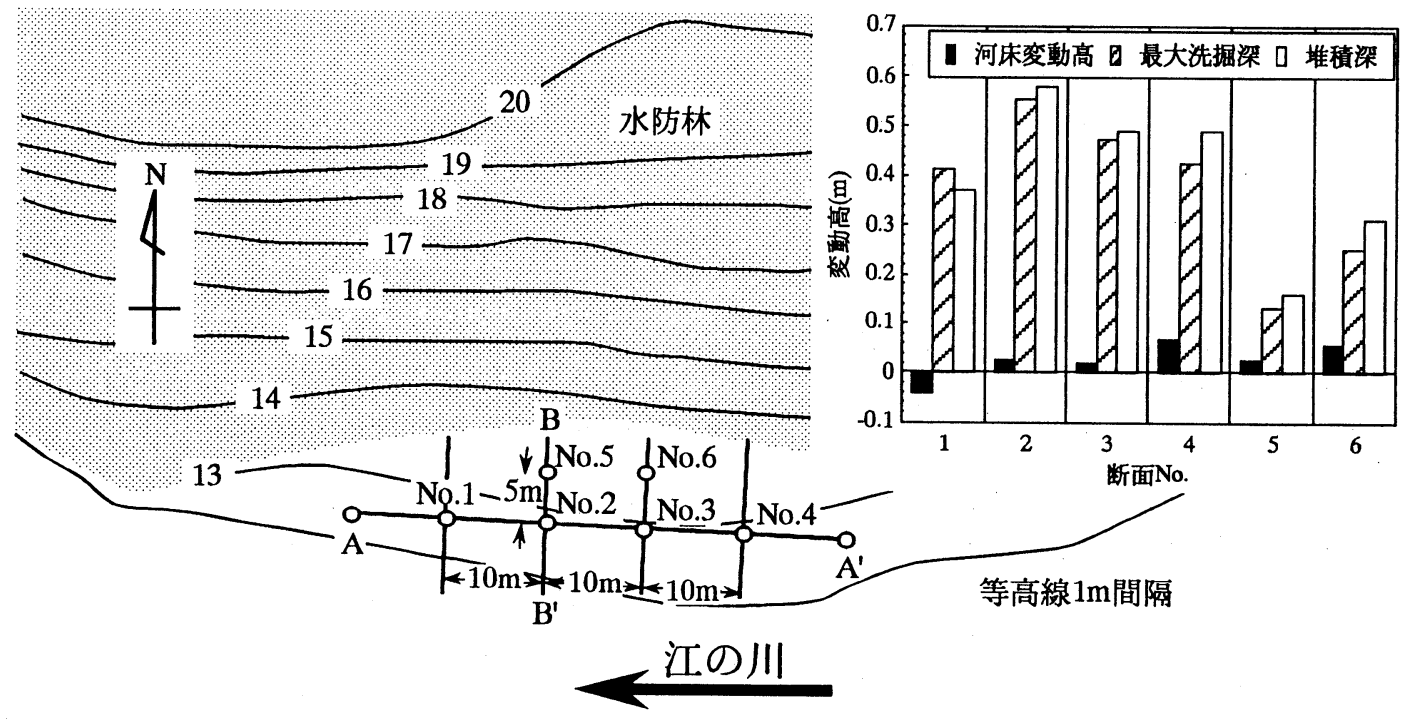

(b) 大貫地点 $(23.7 \mathrm{~km}$ 付近)

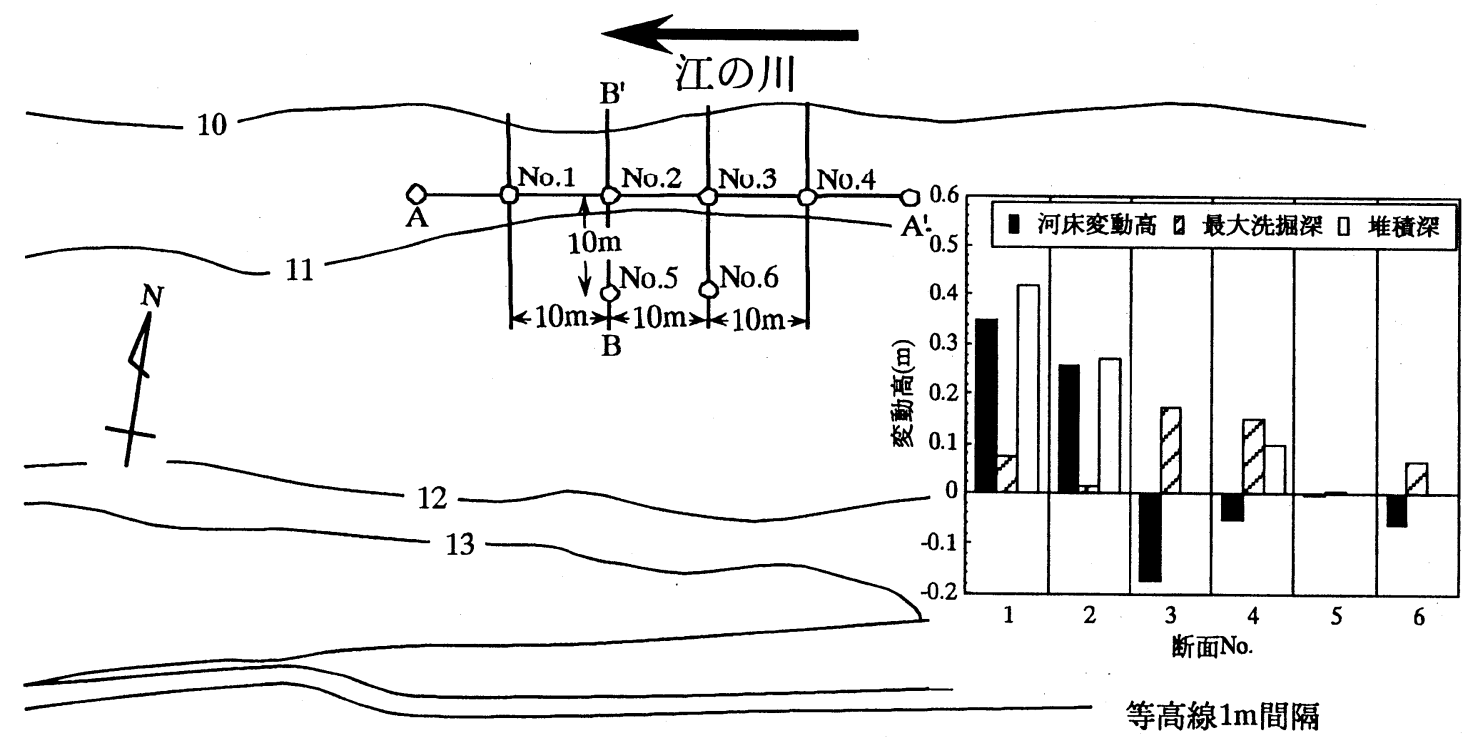

(c) 田津地点 $(21.2 \mathrm{~km}$ 付近)

図-7 内岸洗掘深調査箇所の平面図及び調查結果 
積が起こり, 洪水前の河床高近くまで復したものと 考えられる.

この地点は, 先の渦巻地点と蛇行度に違いはある が，ほぼ同様な平面的な位置関係にある. しかし， 最大洗掘深, 堆積量には差が生じている。この事を 移動床実験結果から検討を試み，推定する.

複断面蛇行流れで水防林の有無の実験結果 ${ }^{83,12,13)}$ 比較すると, 低水路河岸沿いに水防林が存在する場 合，洗掘位置はより内岸側に現れている．そのた め, 大貫地点では洗掘位置がより内岸河岸に近づ き，洗掘深も大きくなったものと思われる．また， 洪水減水時の単断面蛇行流れの時間帯には内岸側に 水防林が存在するため内岸側の流速が極端に遅くな り, 内岸への土砂堆積が助長されたものと思われ る. よって, 低水路内岸側に水防林が存在すると複 断面的蛇行流れの時間帯の内岸河床の変動が大きく なると推定される.

\section{(3) 田津地点 $(21.2 \mathrm{~km}$ 付近)}

田津地点は, 平面的な位置が他の 2 地点と異なり 変曲断面付近の内岸に位置している(図-4).

この地点は, 他の2地点と比べ洪水中の最大洗掘 深が小さい傾向にある. 特に, No.5, 6のボーリン グ孔は洪水を通して殆ど変動していない．実験的な 検討からも変曲点付近の内岸側の河床は, 複断面的 流れ，単断面的流れ，単断面流れを問わず殆ど変動 せず，むしろ堆積が生じる箇所に当たる ${ }^{8,99}$. 今回の 調查結果は, この実験結果とよく対応している.

\section{5. 結論}

洪水時の低水路内岸側河床の最大洗掘深の調查を 行った結果, 次の知見が得られた。

(1)相対水深が大きく, 継続時間の長い大規模な洪水 が発生すると, 蛇行部内岸側の河床が洗掘され ていることが確認された。

(2)蛇行部内岸河床の洗掘深は, 渦巻地点で $0.2 \mathrm{~m}$ 程 度, 大貫地点で $0.4 \mathrm{~m}$ 以上であった. 田津地点 は, 変曲点付近の内岸に位置しているため河床 変動は小さい。

(3)低水路内岸河岸に水防林が存在すると, 内岸側河 床の変動が大きくなる．これは，実験水路での 結果之同様である.

(4)蛇行部内岸側河床の最大洗掘深は, 洪水減水時に は徐々に埋め戻され堆積していく. その堆積深 は, この調査地点では最大洗掘深とほぼ等しい かそれ以下であった.

(5)洪水前後に測定された河床高より得られる河床変 動高は, この調查では洪水中に起こる最大洗掘 深, 堆積深などとの関連は大きくない.
調査は, 現在のところ江の川の渦巻, 大貫, 田津 の3地点だけである. 洪水中の内岸側河床の最大洗 掘深0.4mが大きいか小さいかについては, 現在の之 ころ判断できる段階にない，同様な調査が多くの河 川で行なわれつつあるので, 河道の平面形, 洪水規 模, 河床材料等と関連づけを進め明らかにしていく 方針である.

謝辞 : 本調査, 研究を進めるにあたり, 建設省河川 局治水課より多くの貴重な意見と便宜を頂いた.こ こに記して感謝の意を表します。

\section{参考文献}

1) 藤田光一 : 空から見たミシシッピ・ミズーリ川の破堤 形態，土木技術資料Vol37，No.10，pp.54-59，1995.

2) 芦田和男, 江頭進治, 劉炳義, 滝口将志 : 蛇行低水路 を有する複断面流路における流れの特性と河床変動機 構, 京都大学防災研究所年報, 第32号B-2, pp.527551, 1989.

3) G. Kiely : Overbank flow in meandering compound channels, the important mechanism, Int. Conference on River Flood Hydraulics, pp.207-217, 1990.

4) B. B. Willetts and R. I. Hardwick : Model studies of overbank flow from a meandering channel, Int. Conference on River Flood Hydraulics, pp.197-205, 1990.

5) 武藤裕則, 塩野耕二, 今本博健, 石垣泰輔 : 複断面蛇 行開水路流れの水理特性について (1)，京都大学防 災研究所年報，第38号B-2, pp.561-580, 1995.

6) 福岡捷二, 大串弘哉, 加村大輔, 平生昭二 : 複断面蛇 行流路における洪水流の水理, 土木学会論文集 No .579, II -41, PP.83-92, 1997.

7) 福岡捷二, 宮崎節夫, 高橋宏尚, 加村大輔 : 堤防法線 と低水路法線の間に位相差がある流れの水理, 河道の 水理と河川環境シンポジウム論文集, pp.89. 94, 1995.

8) 福岡捷二, 宮崎節夫, 大串弘哉, 加村大輔 : 堤防と低 水路の法線の間に位相差が存在する複断面蛇行流路の 流れ之河床変動, 水工学論文集, 第 40巻, pp.941946, 1996.

9) 福岡捷二, 渡邊明英, 加村大輔, 岡田将治 : 複断面蛇 行流路における流砂量, 河床変動の実験的研究, 水工 学論文集, 第41巻, pp.883-888, 1997.

10)福岡捷二, 高橋宏尚, 加村大輔 : 複断面蛇行河道の洪 水流に現れる複断面的蛇行流れと単断面的蛇行流れ〜 洪水流航空写真を用いた分析〜，水工学論文集，第41 巻, pp.971-976, 1997.

11)福岡捷二 : 複断面蛇行河道設計法の課題, 第3回河道 の水理と河川環境に関するシンポジウム論文集, pp.18, 1997.

12)福岡捷二, 五十嵐崇博, 高橋宏尚: 江の川水防林の特 性とその治水効果, 水工学論文集, 第39巻, pp.501506, 1995.

13)福岡捷二, 大串弘哉, 川岡秀和 : 水防林のある河道の 流れ特性, 土木学会第 51 回年次学術講演会講演概要 集，第2部，pp.228-229，1996.

(1997.9.30受付) 